\title{
Is Widal test still a usefull method as a routine early diagnostic for typhoid fever in hospitals ?
}

\author{
Sylvia Y. Muliawan ${ }^{*}$, Lucky Hartati Moehario ${ }^{\dagger}$
}

\begin{abstract}
Abstrak
Telah dilakukan penelitian uji Widal untuk mengetahui apakah uji Widal sebagai alat diagnostik dini demam tifoid yang rutin dikerjakan di Rumah Sakit masih bermanfaat pada saat ini. Pada penelitian ini digunakan tiga grup spesimen darah tunggal, yaitu 2 grup spesimen berasal dari pasien rawat inap di Rumah Sakit dengan demam yang telah dikonfirmasikan dengan kultur sebagai positif (grup I) dan negatif (grup II), dan satu grup spesimen orang sehat yaitu donor darah. Hasil uji Widal dinyatakan positif bila titer aglutinin $O$ Salmonella typhi lebih dari 80. Pada uji Widal sensitivitas yang diperoleh adalah 37\%, spesifisitas $97 \%$, nilai prediksi positif $90 \%$, dan nilai prediksi negatif $73 \%$. Akhir-akhir ini berkembang berbagai tes serologi, antara lain metode ELISA dengan menggunakan protein membran luar Salmonella typhi sebagai antigen, yang menunjukkan nilai sensitivitas dan spesifisitas lebih tinggi dibanding dengan uji Widal. Dengan demikian, penggunaan uji Widal secara rutin sebagai alat diagnostik dini demam tifoid perlu dipertimbangkan kembali.
\end{abstract}

\begin{abstract}
In this study, we carried out Widal test to establish whether it is still significant as a routine early diagnostic tool of typhoid fever in the present time. We used three groups of patients: the first two groups were hospitalized patients with fever, of which single blood specimen were taken and confirmed by culture as positive (group I) and negative (group II), and the third group was healthy blood donors. Anti $O$ agglutinin titers regarded as positive were those exceeding 1:80. The sensitivity of single Widal test was 37\%, specificity $97 \%$, positive predictive value $91 \%$, and negative predictive value $73 \%$. Other serology tests developed currently, among others the use of outer membrane protein preparation of Salmonella typhi as an antigen in the ELISA test, have shown higher sensitivity and specificity than the Widal test. Therefore, the use of the Widal test as a routine early diagnostic tool for typhoid fever might need to be reconsidered.
\end{abstract}

Keywords: Salmonella typhi, ELISA test, outer membrane protein, anti $O$ agglutinin

Typhoid fever is an endemic acute systemic illness caused by infection of Salmonella typhi (S. typhi). The disease remains a public health problem in developing countries, including Indonesia. In several countries annual epidemiological data for typhoid fever are obtained from clinical or laboratory results, and as the disease mimics several infectious diseases, it is therefore difficult to obtain a true picture of it.

The best method to detect an infection caused by $S$. typhi is by isolation of the microorganism from clinical specimens. ' This method is, however, time consuming, i.e. it usually takes $2-8$ days, ${ }^{2-7}$ and it depends on laboratory facilities available in the areas. Among

\footnotetext{
* Department of Microbiology, Faculty of Medicine, University of Trisakti, Jakarta, Indonesia

+ Department of Microbiology, Faculty of Medicine, University of Indonesia, Jakarta, Indonesia
}

the many methods of obtaining clinical specimens, blood culture is the one routinely used for the isolation of the microorganism. Although culture may show specificity, it lacks sensitivity mainly if the patients have already taken antibiotic treatments. On the other hand, routine serology test, i.e. Widal test, ${ }^{8}$ although widely used, lacks sensitivity and specificity. For a meaningful interpretation of the test, demonstration of a 4-fold rise in antibody titers between acute and convalescent sera in a 7-14 days interval is essential., 3

Due to those reasons, during the last decade efforts have been carried out in developing newer methods for early diagnosis of typhoid fever. One of the diagnostic methods to be developed is ELISA using outer membrane protein (OMP) preparation as an antigen. ${ }^{9-11}$ Previous studies have indicated the suitability of $S$. typhi OMPs as immunogens in stimulating anti-S. typhi antibodies formation. ${ }^{12-14}$ Earlier study conducted by Moehario, et al. $(1997)^{15}$ showed the 
reactivity of sera of patients with typhoid fever against OMP preparations derived from local $S$. typhi strains, however, the result was not in conformity with others. $3,9,16$ In this study, we reassessed the use of Widal test as an early diagnostic tool for typhoid fever from hospitalized patients and, moreover, compared the significant difference to the earlier published results of ELISA test using OMP preparations derived from local $S$. typhi strain by Muliawan, et al. (1997). ${ }^{11}$

\section{METHODS}

Blood specimens from hospitalized patients in private hospitals were collected from June - November 1997. Twenty-seven specimens, derived from clinically diagnosed typhoid fever patients and were culturepositive for $S$. typhi, will be subsequently designated as group I; 46 specimens derived from clinically diagnosed typhoid fever patients and were culture-negative for S. typhi (groupII); and 70 healthy subjects as group III. Sera from the three groups were tested by the Widal test, using a rapid slide kit (Murex Diagnostica, $\mathrm{SA}$, France). Interpretation of significant anti-O agglutinin titers for recent infection regarded as positive were those exceeding 1:80 (Murex Diagnostica, SA, France). The same specimens were also tested by an ELISA test using local OMP preparation as reported in the earlier publication. ${ }^{11}$ The significant difference was analyzed by 'spearman correlation coefficients' method.

\section{RESULTS}

Results of Widal test of hospitalized patients and compared to culture were shown in Table 1.

Table 1. The results of Widal test and culture in group I and II

\begin{tabular}{lccc}
\hline Widal & \multicolumn{2}{c}{ Culture } & Total \\
\cline { 2 - 3 } & Positive & Negative & \\
\hline Positive & 10 & 1 & 11 \\
Negative & 17 & 45 & 62 \\
\hline Total & 27 & 46 & 73 \\
\hline
\end{tabular}

Sensitivity

Specificity

Positive predictive value (PPV)

Negative predictive value (NPV)
$10 / 27 \times 100 \%=37 \%$

$45 / 46 \times 100 \%=97 \%$

$10 / 11 \times 100 \%=91 \%$

$45 / 62 \times 100 \%=73 \%$

\section{DISCUSSION}

In this study, Widal test was performed only for anti-O agglutinins, while anti-H agglutinins were not evaluated, as they have no diagnostic value in adult patients with fever in endemic areas. ${ }^{11,17}$ of the $27 \mathrm{~S}$. typhi culture-positive blood specimens (group I), 17 were Widal negative. Only one specimen was Widal positive in the $46 S$. typhi culture-negative blood specimens (group II), while all specimens from healthy subjects were Widal negative (group III). These negative results in group I may be due to the fact that the specimens were obtained in the first week of fever, when antibody titer was still undetectable. This is corroborated by Senewiratne, et al. (1977) ${ }^{1}$ who found that in Widal test, the increase in antibody titer to diagnostic levels was generally highest in the second or third week of illness, amounting to $95.7 \%$, while the increase in titer in the first week was just $85.7 \%$. Another possible reason is that the cut off value for positive titer used in the Widal test is not suitable for Indonesian population. Therefore, it is best to use a cut off value for positive results in the Widal test that is directly derived from a population of adults in the endemic area under study. The single Widal positive blood specimen in S. typhi culture-negative specimens (group II) may be explained by a cross reaction with other Salmonella species, due to the similarities of their polysaccharide content of the somatic antigens. The Widal test in group I and group II patients with fever of one week duration, as compared to the results of culture, yielded a sensitivity of $37 \%$, a specificity of $97 \%$, a positive predictive value of $91 \%$, and a negative predictive value of $73 \%$.

Earlier study carried out by Muliawan, et al. (1997) showed that the sensitivity, specificity, positive predictive value and negative predictive value of ELISA test using OMP preparations was $81.5 \%, 100 \%, 100 \%$, and $90.2 \%$, respectively. ${ }^{11}$ The significant difference of the ELISA test in comparison to the Widal, was analyzed statistically by the above mentioned method. The result was $P<0.005$. However, other study conducted by Hasan (1999), ${ }^{18}$ which compared the available dot blot kit (Typhidot $\mathrm{M}$ ) to conventional Widal test showed, in fact, no significant difference between those methods. Seemingly, the use of OMP preparation of $S$. typhi from a local strain as an antigen is more appropriate to our conditions and gives more reliable results than non-local strain $S$. typhi.

\section{CONCLUSION}

In view of the inconclusive results of the single Widal test, its routine use in hospitals as a routine early 
diagnostic tool for typhoid fever might be reconsidered. Further, a more suitable test such the ELISA test using OMP preparations of $S$. typhi as an antigen could be taken into account as an alternative method.

\section{REFERENCES}

1. Senewiratne B, Chir B, Senewiratne K. Reassessment of Widal test in the diagnosis of typhoid fever. Gastroenterology 1977; 73:233-6.

2. Hashimoto $Y$, Itho $Y$, Fujinaga $Y$, Khan $A Q$, Sultana $F$, Miyake M, et al. Development of nested polymerase chain reaction based on Via B sequence to detect Salmonella typhi. J Clin Microbiol 1995; 33 (3):775-7.

3. Ismail A. Development of a Dot EIA for the rapid diagnostic of typhoid fever. In: Pang T, Koh CL, Puthucheary SD, editors. Typhoid fever, strategies for the 90 's. Kuala Lumpur: World Scientific; 1991. p. 201-6.

4. Sadaalah F, Brighouse G, Giudice GD, Dayal RD, Hocine M, Lambert PH. Production of specific monoclonal antibodies to $S$. typhi flagellin and possible application to immunodiagnosis of typhoid fever. J Infect Dis 1990; 161:59-64.

5. Sarasombath S, Lertmemongkolchai G, Banchuin N. Characterization of Monoclonal antibodies to protein antigen of S. typhi. J Clin Microbiol 1988; 26 (3):508-12.

6. Song JH, Cho H, Park MY, Na DS, Moon HB, Pai CH. Detection of $S$. typhi in the blood of patients with typhoid fever by polymerase chain reaction. J Clin Microbiol 1993; 31:1439-43.

7. Sukosol T, Sarasombath S, Mongkolsuk S, Chaiyaroj S, Ekpo P. Molecular cloning of a $52 \mathrm{k}$ Da specific protein antigen of $S$. typhi. In: Pang T, Koh CL, Puthucheary SD, editors. Typhoid fever, strategies for the 90's. Kuala Lumpur: World Scientific, 1991. p. 43-51.

8. Schroeder SA. Interpretation of serologic tests for typhoid fever. Jama 1968; 206 (4):839-40
9. Rodriquez AV, Gam LH, Devi S, Koh CL, Puthucheary SD, Calva E, et al. Detection of antibodies against outer membrane protein preparation in typhoid fever patients. Asian Pacific J of Allergy Immunol 1993; 11:45-52.

10. Rodriquez AV, Vidal YL, Puente JL, Palacios GMR, Calva E. Early diagnostic of typhoid fever by an enzym immunoassay using $S$. typhi outer membrane protein preparation. Eur J Clin Microbiol Infect Dis 1993; 12 (4): 248-54.

11. Muliawan SY, Sudarmono P, Moehario LH. Enzyme linked immunoassay for early diagnosis of typhoid fever using $S$. typhi outer membrane protein. Med J Indones 1998; 7 suppl 1:211-3.

12. Udhayakumar V, Muthukkaruppan VR. Protective immunity induced by outer membrane proteins of $S$. typhi murium in mice. Infect Immun 1987; 55 (3):816-21.

13. Isibasi A, Ortiz V, Vargas M, Paniagua J, Gonzalez C, Moreno J, et al. Protection against $S$. typhi infection in mice after immunization with outer membrane proteins isolated from S. typhi 9, 12, d, Vi. Infect Immun 1988; 56 (11):29539.

14. Ortiz V, Isibasi A, Ortigoza EG, Kumate J. Immunoblot detection of class-specific humoral immune response to outer membrane proteins isolated from $S$. typhi in human with typhoid fever. J Clin Microbiol 1989; 27 (7):1640-5.

15. Moehario LH, Firdaus ES, Sudarmono P. Assessment of reactivities of typhoid fever sera against outer membrane protein preparations from strain of $S$. typhi in Jakarta. Med J Indones 1998; 7 suppl 1:44-8.

16. Calderon, Lobos SR, Rojas HA, Palomino C, Rodriquez LH, Mora GC. Antibodies to porin antigens of Salmonella typhi induced during typhoid infection in humans. Infect Immun 1986; 52:209-12.

17. Levine MM, Grados O, Gilman RH, Woodward W, Plaza RS, Waldman W. Diagnostic value of the Widal test in area endemic for typhoid fever. Am J Trop Med Hyg 1978; 27 (4):795-800.

18. Hasan I. Typhidot test and scoring system in the diagnosis of typhoid fever. [Thesis]. Jakarta: Faculty of Medicine University of Indonesia; 1999. 